\title{
Ultrastructural Analysis of Masseter and Left Medial Pterigoid Muscles, After Unilateral Mandibular Molar Extraction: Experimental Study
}

\author{
Análisis Ultrastructural de los Músculos Masetero y Pterigoideo Medial Izquierdo, \\ después de la Extracción Molar Mandibular Unilateral: Estudio Experimental
}

\begin{abstract}
Maria Ivone Mendes Benigno ${ }^{1}$; Edson Aparecido Liberti' ${ }^{2}$;irton Mendes Conde $\mathrm{Jr}^{3}$; Noélia Maria de Sousa Leal ${ }^{3}$; Karla Emanuelle Lopes Rodrigues ${ }^{3}$; Vanessa Benigno Mota ${ }^{3}$ \& Eliane Maria Ingrid Amstalden ${ }^{1}$
\end{abstract}

BENIGNO, M. I. M.; LIBERTI, E. A.; CONDE JR., A. M.; DE SOUSA LEAL, N. M.; LOPES RODRIGUES, K. E.; MOTA, V. B. \& AMSTALDEN, E. M. I. Ultrastructural analysis of masseter and left medial pterigoid muscles, after unilateral mandibular molar extraction: experimental study. Int. J. Morphol., 35(2):430-434, 2017.

SUMMARY: Twelve adult male Wistar rats (220 g average weight) were divided in 3 experimental groups: GI - 15 . GII - 30 and GIII - 60 days, after mandibular molar extraction, with three experimental animals and one control per group. Qualitatively, ultrastructural changes of protein filaments from myofibrils of these muscles and ipsilateral to the extractions were observed. Ultrastructure asymmetry and disorganization of $\mathrm{Z}$ line and I band, in the experimental group GII, of Medial Pterigoid muscle (MPT) were observed. The temporomandibular dysfunction, stimulated by the unilateral extractions of mandibular molars in rats may lead to modifications in the $\mathrm{Z}$ line and I band, which showed to be sensitive to this dysfunction. Changes in the MPT muscle, probably related to its own functional characteristics and major participation in the dynamics of mastication, compared to Masseter were also observed. However, the muscular fibres seem to adapt to the new conditions along the experiment.

KEY WORDS: Skeletal muscular fibre; Masticator muscles; Occlusal alterations; Temporomandibular joint; Transmission electron microscopy.

\section{INTRODUCTION}

Mastication is strongly associated with the temporomandibular joint (TMJ) and to masticatory muscles. The majority of temporomandibular dysfunction (TMD) has occlusal alterations as predisposing or coadjutant factor, which has been identified as responsible for the impairment of masticatory muscles. The jaw elevator muscles keep the mandibular physiological postural position against gravity action, emphasizing the Masseter, Medial Pterigoid and Temporal muscles. According to Dawson (2008), occlusal alterations in human dentition can cause painful symptomatology, due to the accumulation of toxins resulting from the concentration of products from the cellular metabolism. Cao et al. (2010) investigated the Masseter muscle histological alterations, concluded that in the occlusal interferences, the muscular pain experimentally induced is associated WITH peripheral sensitization of nociceptive neurons, instead of muscular lesion and inflammation. The MPT and Masseter muscles act synergistically to elevate jaw and contribute to its protrusion. There is a synchrony between masticatory muscles and TMJ in masticatory activity, as related by Iyomasa et al. (2008, 2009), who investigated the ultrastructural and histological effects over the MTP muscle of gerbils in occlusal alterations induced by unilateral extraction. These studies showed, through micrograph data, that unilateral teeth extraction was able to induce modifications in PTM muscle fibres and capillaries. Many factors can lead to occlusal disharmony such as: tooth loss (Miehe et al., 1999; Benigno et al., 2001; Bazan et al., 2008); premature contact in dental occlusion (Bakke M.,1993); use of orthodontic braces and dentures (Cvetko et al., 2012) wear and abrasion of occlusal surface of teeth (Bani et al.,1999; Santiwong et al., 2002). Some studies discuss the effects of occlusal disharmony in human stomatognathic system. Bani et al.; Benigno et al., Korfage et al. (2000), Benigno et al., studied the alterations in the bilaminar zone of TMJ, in young adults and elders, and verified alterations of collagen and elastic fibers in the different

\footnotetext{
${ }^{1}$ School of Medical Sciences, State University of Campinas, Campinas, Brazil.

${ }^{2}$ Department of Anatomy, University of São Paulo, São Paulo, São Paulo, Brazil.

${ }^{3}$ Department of Morphology, Federal University of Piaui, Teresina, Piaui, Brazil.

Funding: This work was supported by CAPES.
} 
BENIGNO, M. I. M.; LIBERTI, E. A.; CONDE JR., A. M.; DE SOUSA LEAL, N. M.; LOPES RODRIGUES, K. E.; MOTA, V. B. \& AMSTALDEN, E. M. I. Ultrastructural analysis of masseter and left medial pterigoid muscles, after unilateral mandibular molar extraction: experimental study. Int. J. Morphol., 35(2):430-434, 2017.

age groups, in which they observed morphological alterations in the collagen fibers of elders. Animal models have been stimulated due to the limitations of experiments in humans and to the anatomic and functional similarity to the human masticatory muscles. Studies have been carried out with different animal models and under various aspects about the macroscopic, microscopic and ultrastructural findings of masticatory muscles. The pathophysiological mechanisms to muscular adaptation remain poorly comprehended, and more studies related to pathological and morphofunctional alterations are necessary. Zhou et al. (2012), investigated the ultrastructural and proteinaceous alterations in the surface of Masseter muscle in rats. They demonstrated the deregulation of myofibrils followed by rupture, interlacing of myofilaments, changings in the amount and localization of mitochondrias, that were located in large amounts both in the subsarcolemmal region and in the regions between the myofibrils, and increase in vesicles of the sarcoplasmic reticulum cisterns.

\section{MATERIAL AND METHOD}

Sample characterization and division of groups of animals. Twelve one-month-old rats from Wistar lineage, weighing on average $220 \mathrm{~g}$, male, from the Central Vivarium of Federal University of Piauí were used. Initially, the animals were kept in an adequate environment, distributed in acrylic cages of $30 \times 19 \times 16 \mathrm{~cm}$ in length, containing one animal each, which were cleaned daily. All the animals were previously submitted to clinical evaluation to guarantee their state of health. The diet was a normally kept ration and water ad libitum-based. The animals were divided into three groups according to the distinct evolution period analysed: 15 days (GI); 30 days (GII) and 60 days (GIII), after extraction of mandibular molars, each experimental group with three animals and the control groups with one animal. The control groups were not submitted to any pharmacological or surgical protocol. The Ethics Committee in Animal Experimentation - CEEA/UFPI, approved under the number $072 / 11$, all the procedures of this study.

Surgical procedure. The animals in experimental groups were submitted to left mandibular molars extraction (Figure 1) to induce the dysfunction of TMJ. For this procedure, the animals were pre-medicated with opioid ( $6 \mathrm{mg}$ tramadol $/ \mathrm{kg}$ ) by deep intramuscular injection to ensure analgesia. After ten minutes they were submitted to general anaesthesia dissociative kind, where the anaesthetic association ketamine (Dopalen) 50mg/ $\mathrm{k}$, xylazine (Rompum) $0,5 \mathrm{mg} / \mathrm{kg}$ was used in the same syringe, injected via intramuscular. Once the surgical procedures (extractions) concluded the animals were submitted to preventive antibiotic therapy (Penicillin / streptomycin -
$40.000 \mathrm{UI} / \mathrm{kg}$ ) by deep intramuscular injection and antiinflammatory (Flunixin meglumine $1,0 \mathrm{mg} / \mathrm{kg}$ ) every twentyfour hours for a period of three days. An adapted Weingart ${ }^{\circledR}$ $120 \mathrm{E}$ pliers (Fig. 2) was used for the extractions. The post operatory was daily evaluated and the animals were kept under technical care from vivarium, during the experimental period.

At the end of each period: 15 days (Group I); 30 days (Group II) and 60 days (Group III) euthanasia of animals from experimental group was carried out with the corresponding control group. This technique was conducted under the following protocol: firstly, the animals were pre-medicated with opioid (tramadol $6 \mathrm{mg} / \mathrm{kg}$ ) by deep intramuscular injection to ensure analgesia. After ten minutes, general anaesthesia of dissociative kind was performed, in which anaesthetic association with ketamine (Dopalen) $50 \mathrm{mg} / \mathrm{kg}$ Xylazin (Rompum) 0,5 mg/kg was used in the same syringe, injected via intramuscular. The intracardiac infusion was carried out with Karnovsky solution (2.5\% glutaraldehyde and $2 \%$ paraformaldehyde in $0.1 \mathrm{M}$ buffered with sodium phosphate / $\mathrm{pH}=7.3$ ). From each animal, fragments $0.3 \mathrm{~cm}$ thick in transverse sections were isolated from the profound region of the left Masseter muscle and from the middle portion of the left MPT muscle. These ones were re-fragmented in multiple slim fragments, fixed in modified Karnovski solution and subsequently immersed in glutaraldehyde solution for two hours. The material was rinsed in saline and post-fixed with osmium tetroxide $\left(\mathrm{O}_{\mathrm{s}} \mathrm{O}_{4}\right)$ to $2 \%$ for a period of $2 \mathrm{~h}$ at $4{ }^{\circ} \mathrm{C}$. The material remained overnight in a third post-fix, the uranyl acetate. After this period, dehydration started by passing the material through an ascending series of ethanol: $70^{\circ}, 80^{\circ}, 90^{\circ}$ and $95^{\circ}$ baths during 15 minutes, four baths in absolute ethanol of $15 \mathrm{~min}$ each, and two baths oxide propylene 15 minutes each. After these baths, the infiltration, composed of a mixture of resin and propylene oxide in the ratio of 1:1 was carried out for a period of $40 \mathrm{~min}$, then changing to $3: 1$, for $1: 30 \mathrm{~h}$. Then moved to pure resin, overnight, always on the rotary shaker. After this period, the process of inclusion of the material was performed, which remained in the oven for 3 days at $60^{\circ} \mathrm{C}$. After this period, the block prepared for the trimming of which semi-thin sections were taken at $300 \mathrm{~nm}$, and observed under an optical microscope to select the best ultrathin sections with $60 \mathrm{~nm}$. Specific graticule with 200 mesh was used to support the material for posterior analysis in a transmission electron microscope. This study consisted of a qualitative observation of ultrastructural findings of the filaments of some proteins of the myofibrils ( $\mathrm{Z}$ line and band I) of the Masseter and MPT muscles in different evolutional periods of 15, 30 and 60 days. Ethical approval: I state that the animal care and the experimental procedures were in accordance with the Ethics Committee on Animal Research of the Federal University of Piauí, protocol number CEEA Nº72/11. Resolution n¹96/ 96 do CNS. 


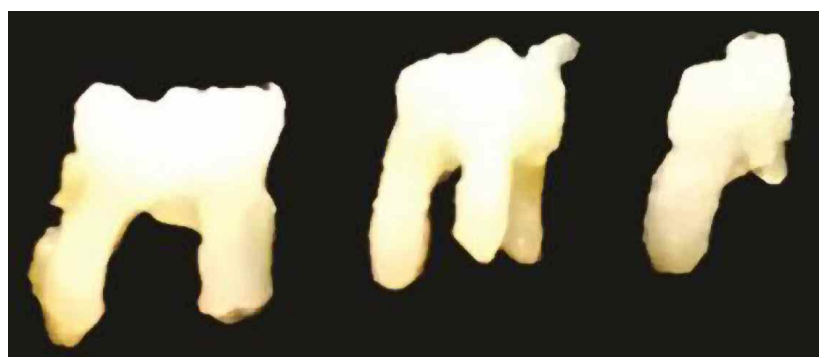

Fig. 1. Mandibular molar teeth extracted from Wistar rat.

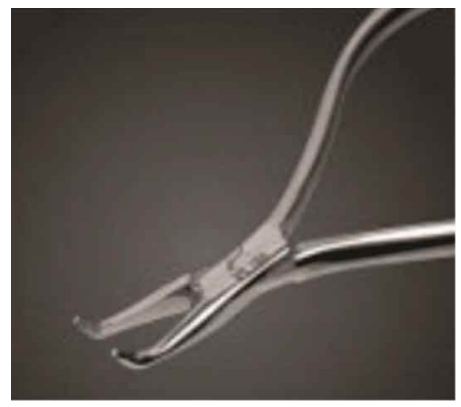

Fig. 2. Pliers used in the molar extractions $\left(\right.$ Wengart $\left.{ }^{\circledR}\right)$.

\section{RESULTS}

Ultrastructure of muscular fibres. This analysis showed structural damage at the level of MPT muscle, in the GII group, corresponding to 30 days of experiment, in which alteration in the myofibrils was observed, characterized by the disorganization and asymmetry of their protein filaments, corresponding to $\mathrm{Z}$ line and I band (Fig. 3C). In the control group (Fig. 3A) ultrastructural alterations in the $\mathrm{Z}$ line and I band were not observed. Groups GI and GII did not present alterations either, and it is possible to observe fibres harmonically distributed in these groups.

In the Masseter muscle, these structures remained symmetric and organized in all the examined groups (Fig. 4). Both the control group CG (Fig. 4A), and the experimental groups (Fig. 4B, C and D), kept their ultrastructural characteristics unchanged.
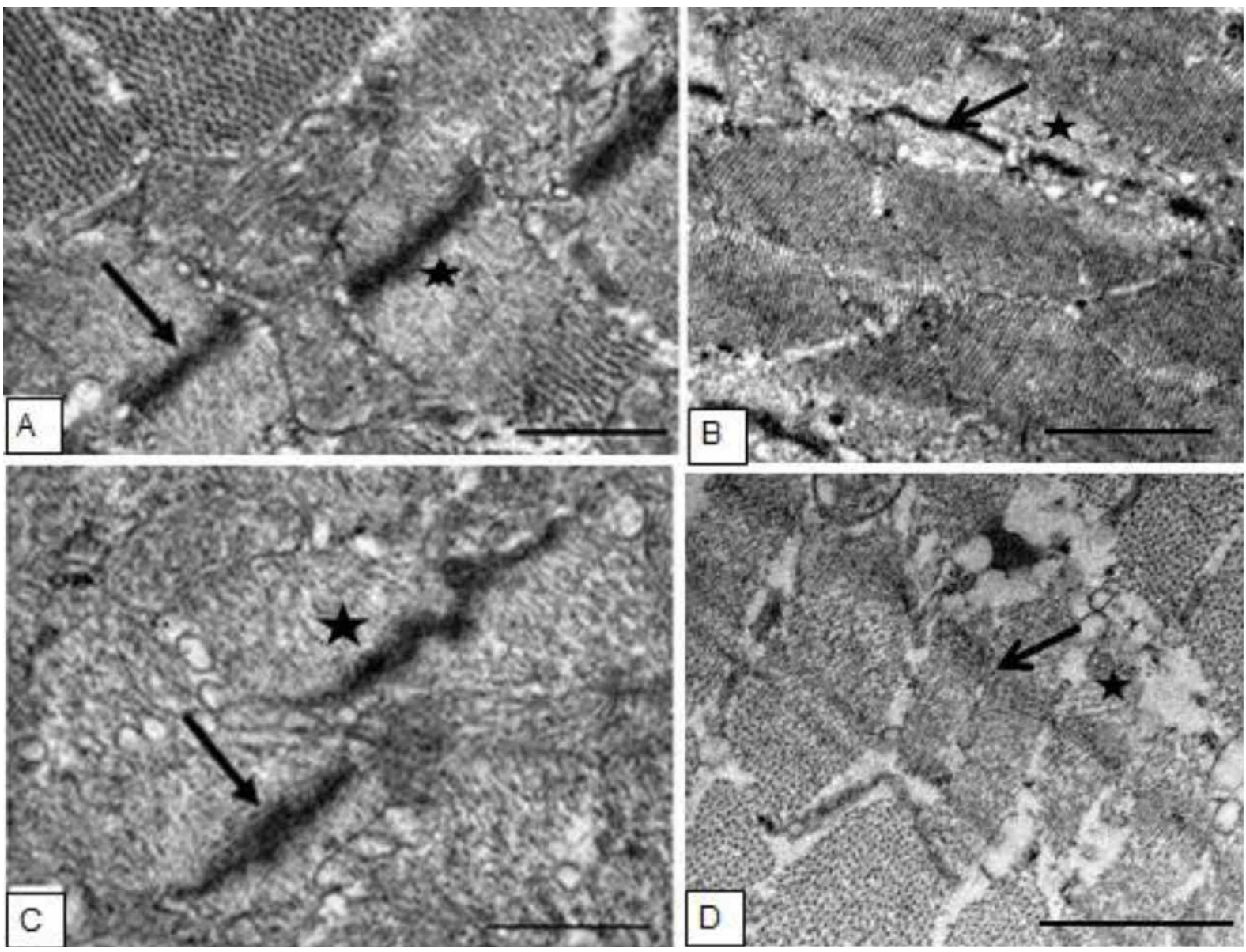

Fig. 3. Ultrastructure of left MPT muscle (A) control and experimental group GI (B), GII (C) e GIII (D). Note in the GII (C) group a clear disorganization in the $\mathrm{Z}$ lines (arrows) among the I bands (*). Compare to the control group (A)and the experimental group (B, D), where these show symmetrical and organized layout (Calibration bar: $1 \mathrm{~mm}$ ). 

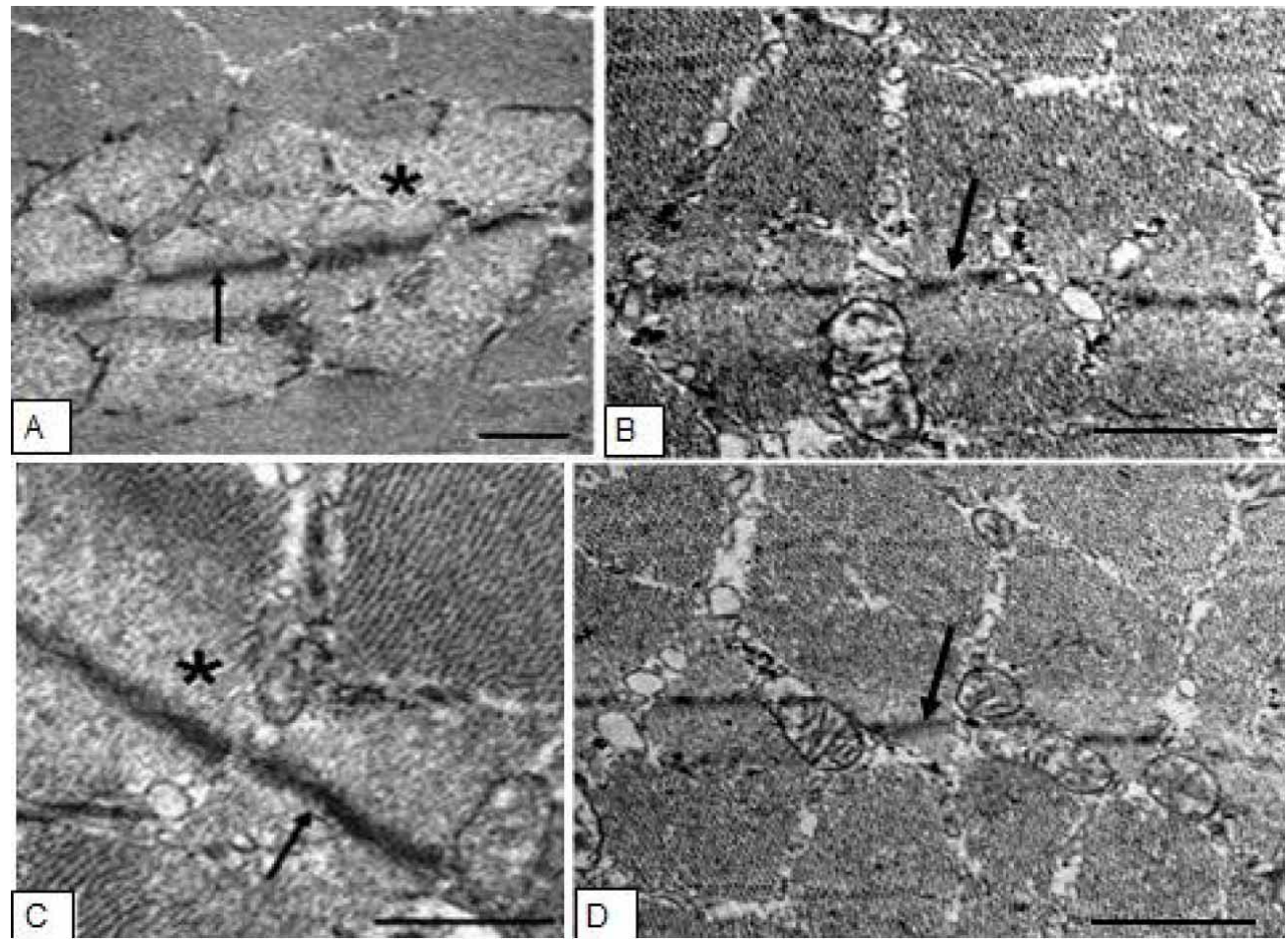

Fig. 4 - Ultrastructure of masseter muscle. (A) control and experimental groups: GI (B), GII (C) and GIII (D). Note that in all groups the $\mathrm{Z}$ lines (arrows) and I bands present symmetric, organized layout. (A-calibration bar: 0,5 mm) (BD calibration bar: 1,0 $\mathrm{mm}$ ).

\section{DISCUSSION}

The masticatory movements are directly related to the masticatory muscles. Any disharmony of the stomatognathic system may cause consequences to this musculature. Very few studies discuss the effects of occlusal disharmony in the human stomatognathic system (Benigno et al.; Sciote et al., 2012; Korfage et al.). The author's previous study (Benigno et al.) showed that the bilaminar zone of the human temporomandibular joint (TMJ), a component of stomatognatic system presents morphological alterations when compared qualitatively structure in young individuals (toothed) and those elderly (edentulous). Animal models as those by Easton \& Carson, 1990; Iyomasa et al., 2008, 2009; Cvetko et al.; Carison \& Easton; Benigno et al., have been encouraged due to the limitations of these experiments in humans.

In this study, the choice Wistar rat as an experimental model was based on the similarity to the human, regarding anatomy, location and architectural arrangement of the masseter muscle and MPT, as described Seiryu et al., 2012. Morphological analysis has contributed little in change detection of skeletal muscle fibers (Iyomasa et al., 2008; Cvetko et al.; Easton \& Carson; Nishide et al., 2001). However, studies by ultrastructure have been the subject of research in striated skeletal muscles (Bazan et al.; Iyomasa et al., 2009).

The ultrastructure of muscle fibers, transverse sections, in this study, was based on the analysis of protein filaments, constituents of myofibrils. These showed asymmetrical distribution and disorganization of the $\mathrm{Z}$ line and band I, only on the left MPT muscle in GII. Ultrastructural changes were also observed by Iyomasa et al. (2008), that occurred in the MPT transverse cuts of the control group in gerbils after extraction of the maxillary molars that most of the cytoplasm was composed by myofibrils. In the MPT ipsilateral experimental group found low density myofibrils constituents of the cytoplasm. No changes were detected at the level of Masseter. Other ultrastructural aspects were observed (Bazan et al.; Iyomasa et al., 2009), which showed, mitochondria with irregular distribution and concentrated near the subsarcolema and not among the myofibrils in the MPT, as usual, after sixty days of extraction. We also found intraluminal protrusion of endothelial cells and numerous vesicles with pinocytosis aspect. Zhou et al. in the ultrastructural analysis of the masseter muscle of rats, found changes in the amount and location of mitochondria, these were located in large quantities, both in the subsarcolemmal region and in the regions between the myofibrils. In our study, these cellular components analyzed 
by the authors above have not been evaluated. The PTM muscle was more sensitive than the Masseter, to temporomandibular dysfunction, This finding is probably related to its characteristics of its own functional biomechanics, more dynamic the jaw movements compared to the Masseter (Moore et al., 2007).

In conclusion, the temporomandibular dysfunction, promoted by unilateral extraction of mandibular molars in Wistar rats, can lead to the $\mathrm{Z}$ line and I band changes ofmuscle cytoskeleton, which are the most sensitive to this dysfunction in the Medial pterygoid muscle (MPT), when compared to the Masseter muscle. The Medial pterygoid muscle (MPT), proved to be more vulnerable in this experimental model, probably by their own performances and greater participation in the dynamics of masticatory movements, compared to the Masseter. This seems to have greater functional reserve.

The results found in the analyzed muscles after occlusal change induction, need special attention to clarify the adaptation of the fibers during the experimental period, a fact that will contribute to the elucidation of problems caused by tooth loss.

ACKNOWLEDGEMENTS. The authors would like to thank to UNICAMP, USP and UFPI for their support.

BENIGNO, M. I. M.; LIBERTI, E. A.; CONDE JR., A. M.; DE SOUSA LEAL, N. M.; LOPES RODRIGUES, K. E.; MOTA, V. B. \& AMSTALDEN, E. M. I. Análisis ultrastructural de los músculos masetero y pterigoideo medial izquierdo, después de la extracción molar mandibular unilateral: estudio experimental. Int. J. Morphol., 35(2):430434, 2017.

RESUMEN: Doce ratas Wistar machos adultos $(220 \mathrm{~g}$ de peso promedio) se dividieron en 3 grupos experimentales: GI - 15, GII - 30 y GIII - 60 días, después de una extracción molar mandibular. En cada grupo se dispusieron tres animales experimentales y un animal como control. Cualitativamente, se observaron cambios ultraestructurales de filamentos de proteínas de miofibrillas de estos músculos masticadores ipsilaterales a las extracciones. Se observó asimetría de la ultraestructura y desorganización de la línea $\mathrm{Z}$ y la banda I, en el músculo pterigoideo medial del grupo experimental GII, (MPT). La disfunción temporomandibular, estimulada por las extracciones unilaterales de los molares mandibulares en ratas, puede conducir a modificaciones en la línea $\mathrm{Z}$ y en la banda I, que mostraron ser sensibles a esta disfunción. Los cambios en el músculo pterigoideo medial, se debieron, probablemente, con sus propias características funcionales y una mayor participación en la dinámica de la masticación, en comparación con el músculo masetero. Sin embargo, las fibras musculares parecen adaptarse a las nuevas condiciones a lo largo del experimento.

PALABRAS CLAVE: Fibra muscular esquelética; Músculos masticadores; Alteraciones oclusales; Articulación temporomandibular; Microscopía electrónica de transmisión.

\section{REFERENCES}

Bani, D.; Bani, T. \& Bergamini, M. Morphologic and biochemical changes of the masseter muscles induced by occlusal wear: studies in a rat model. J. Dent. Res., 78(11):1735-44, 1999.

Bazan, E.; Issa, J. P.; Watanabe, I. S.; Mandarim-de-Lacerda, C. A.; Del Bel, E. A. \& Iyomasa, M. M. Ultrastructural and biochemical changes of the medial pterygoid muscle induced by unilateral exodontia. Micron, 39(5):536-43, 2008.

Benigno, M. I.; Azeredo, R. A.; Lemos, J. L.; König Júnior, B. \& Liberti, E. A. The structure of the bilaminar zone in the human temporomandibular joint: a light and scanning electron microscopy study in young and elderly subjects. J. Oral Rehab., 28(2):113-9, 2001.

Cao, Y.; Li, K.; Fu, K. Y. \& Xie, Q. F. Experimental occlusal interference induces the expression of protein gene products and substance $P$ in masseter muscles of rats. Beijing Da Хие Хие Bao, 42(1):50-5, 2010.

Cvetko, E.; Karen, P. \& Erzen, I. Wearing of complete dentures reduces slow fibre and enhances hybrid fibre fraction in masseter muscle. J. Oral Rehabil., 39(8):608-14, 2012.

Dawson, P. E. Oclusão Funcional - Da ATM ao Desenho do Sorriso. São Paulo, Editora Santos, 2008.

Easton, W. J. \& Carlson, D. S. Adaptation of the lateral pterygoid and superficial masseter muscles to mandibular protrusion in the rat. Am. J. Orthod. Dentofacial Orthop., 97(2):149-58, 1990.

Iyomasa, M. M.; Issa, J. P.; de Oliveira, F.; Stuani, M. B.; de Oliveira, A. M. \& Watanabe, I. S. Morphological and histological effects on the medial pterygoid muscle after unilateral exodontia in gerbils. Micron, 39(7):78590, 2008.

Iyomasa, M. M.; Issa, J. P.; Sosthines, M. C.; Olveira, A. M.; Stuani, M. B.; Motoyama, A. A. \& Watanabe, I. S. Ultrastructural characteristics of the gerbil pterygoid medial muscle after experimental occlusal alteration. Micron, 40(2):206-11, 2009.

Korfage, J. A.; Brugman, P. \& Van Eijden, T. M. Intermuscular and intramuscular differences in myosin heavy chain composition of the human masticatory muscles. J. Neurol. Sci., 178(2):95-106, 2000.

Miehe, B.; Fanghänel, J.; Kubein-Meesenburg, D.; Nägerl, H. \& SchwestkaPolly, R. Masticatory musculature under altered occlusal relationships--a model study with experimental animals. Ann. Anat., 181(1):37-40, 1999.

Moore, K. L.; Dalley, A. F. \& Agur, A. M. Anatomia Orientada para a Clinica. $5^{\mathrm{a}}$ ed. Rio de Janeiro, Guanabara Koogan, 2007.

Nishide, N.; Baba, S.; Hori, N. \& Nishikawa, H. Histological study of rat masseter muscle following experimental occlusal alteration. J. Oral Rehabil., 28(3):294-8, 2001.

Santiwong, P.; Muramoto T.; Soma, K. \& Takano, Y. Growth-associated protein-43 immunohistochemical and ultrastructural changes in jaw muscle spindles of the rat following loss of occlusion. Arch. Oral Biol., 47(3):22737, 2002.

Sciote, J. J.; Horton, M. J.; Rowlerson, A. M.; Ferri, J.; Close, J. M. \& Raoul, G. Human masseter muscle fiber type properties, skeletal malocclusions, and muscle growth factor expression. J. Oral Maxillofac. Surg., 70(2):4408, 2012.

Zhou, D.; Bai, Y. \& Che, X. Ultrastructural and proteomic alteration of superficial masseter muscle after lower jaw sagittal advancement in rat. Arch. Oral Biol., 57(5):436-44, 2012.

Corresponding author:

Dr. Maria Ivone Mendes Benigno

Dr. em Ciências Médicas - UNICAMP

Mestre em Anatomia Humana - USP- SP/SP

Campinas

São Paulo

BRAZIL

Received: 13-06-2016

Accepted: 11-01-2017

E-mail: ivonebenigno@hotmail.com 